\title{
How photographs can be a complement of herbarium vouchers: A proposal of standardization
}

\author{
Carlos Gómez-Bellver, ${ }^{1}$ (1) Neus Ibáñez, ${ }^{2}$ (1) Jordi López-Pujol, ${ }^{2}$ Neus Nualart ${ }^{2}$ (1) \& Alfonso Susanna ${ }^{2}$ (i) \\ 1 Unit of Botany and Mycology, Department of Evolutionary Biology, Ecology and Environmental Sciences, Faculty of Biology, \\ University of Barcelona, av. Diagonal, 643, 08028 Barcelona, Catalonia, Spain \\ 2 Botanic Institute of Barcelona, IBB, CSIC-ICUB, pg. del Migdia, s/n, 08038 Barcelona, Catalonia, Spain \\ Author for correspondence: Alfonso Susanna, asusanna@ibb.csic.es
}

DOI https://doi.org/10.1002/tax.12162

\begin{abstract}
Challenges in the collection of vouchers, either because of the physical properties of the material (species difficult to collect or to press, e.g., palms, cycads, toxic plants, and cacti) or because drying may have a negative effect on taxonomic characters (e.g., colour), recommend the use of photographs to complement herbarium specimens. In a series of cases (enumerated in the present contribution), however, it may be impossible to collect material (of protected species or plants located in inaccessible places), and, thus, photographs may be the only option to document the presence of a plant in a given locality. We propose in this paper some guidelines for the standardization of photographs intended for deposit in herbaria.
\end{abstract}

Keywords CITES; herbaria; photography; vouchers

\section{INTRODUCTION}

The use of photographs to complement herbarium specimens is not new; botanists have sometimes included images, even black and white, to illustrate the collected plants. Some examples can be found in herbarium collections, e.g., a specimen of Juniperus communis L. collected in 1934 with a photograph of detail and another of the whole plant (http://www. ibb.csic.es/herbari/JPEG/BC81104.jpg), a specimen of Agave $\times$ ajoensis W.C.Hodgs. collected in 1987 with colour photos of the habitat of the plant (https://plants.jstor.org/stable/10. 5555/al.ap.specimen.des00030831), or a specimen of Ophrys argensonensis J.-C.Guérin \& A.Merlet collected in 1998 with detailed colour photographs of the flowers (https://plants.jstor. org/stable/10.5555/al.ap.specimen.p00118190). Usually, these photographs provide recording details that are unavailable on dried specimens, or illustrate the habitat where the plants were collected.

Indeed, photographs have been much used in horticulture, because some cultivars can only be identified by an exact colour (Miller, 1995) that may be lost during the drying process. According to the International Code of Nomenclature for Cultivated Plants (ICNCP, cf. Brickell \& al., 2016), a nomenclatural standard (equivalent to the type material in the International Code of Nomenclature for algae, fungi, and plants - ICN, cf. Turland \& al., 2018) can be an image when essential characteristics are best recognized in drawings or photographs, rather than in dried specimens.

Modern technology offers the possibility of increasing the use of photographs to complement herbarium specimens. The advent of digital photography has democratized and simplified photo documentation by removing the constraints of analog photography. These constraints included the economic ones, as quality analogue cameras were expensive, but there were also costs associated with film purchase and developing and printing the photographs. Digital photography has drastically reduced the weight and size of the cameras and eliminated the large amount of film thanks to modern memory cards that can store thousands of photographs. Nowadays, it is no longer necessary even to carry a digital camera: the built-in cameras of mobile phones that are currently marketed allow sufficient quality for nature photography at a professional level (Minteer \& al., 2014).

Here we list those cases where including photographs in a herbarium specimen considerably increases its taxonomic value:

1 Large species: anyone who has collected a herbarium sheet from a palm tree, a cycad or an arborescent fern knows the difficulties involved; not only because of the problem of picking the material and pressing it but also because of the volume. A complete individual of Chamaerops humilis L. occupies the same space as 50 sheets of annual plants (C. Gómez-Bellver \& al., pers. obs.). Photographs of the whole plant and the habitat may constitute an important complement to a small sample collected from the plant (see example in Fig. 1).

2 Succulent and/or spiny plants: the difficulties of preparing sheets of these species are multiplied in the case of succulent plants by the complexity of drying. In addition, we should also consider the possible presence of thorns, spines, or teeth (Cactaceae, Agavoideae, or some taxa of Acacia 

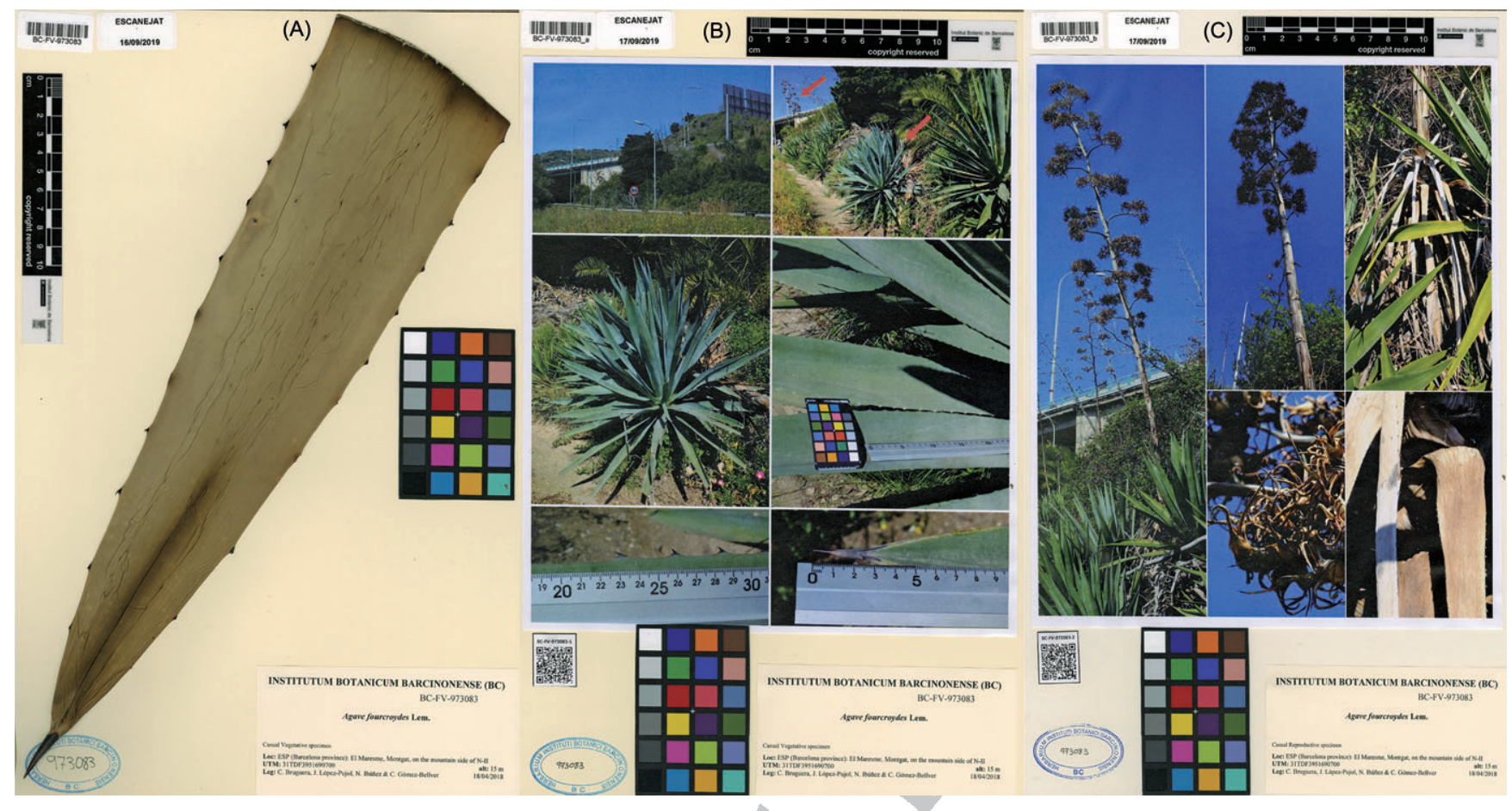

Fig. 1. Fusion voucher of Agave fourcroydes Lem. (BC-FV-973083) from Montgat, near Barcelona City (Catalonia, Spain). This voucher includes both photographs and parts of the plant, and it is composed of three sheets: one (A) is the terminal part of a leaf, the second (B) is a series of pictures of the vegetative individual (from which the leaf was taken), and the third one (C) includes pictures of a flowering individual from the same population. We recommend, when possible, to include a picture in which the two specimens (vegetative and reproductive) are shown. In order to identify both specimens, red arrows are included in one of the photographs of the habitat.

Mill.). In these cases, photographs of the aspect of the plant before drying are a good complement to the physical specimen, which can be limited to a small part of the plant easy to carry and press (such as a small leaf portion or the terminal spine; Fig. 1).

3 Toxic plants: the toxicity of some species may recommend collecting just a small part of the plant with gloves and complement it with photographs. Examples include plants with toxic or irritant latex such as several species of Euphorbia L., plants with phototoxic substances found in the leaves of many species of Heracleum L. or Lantana L., or plants with urticant hairs, such as Wigandia urens (Ruiz \& Pav.) Kunth.

4 Withered plants from which only seeds are collected for seed banks: in these cases, only a small part of the plant is useful as a specimen, because the plant is not suitable for pressing. A specimen is needed to voucher for the individual from which the seeds have been obtained, and the use of photographs can show the aspect of the plant.

5 Plants that, once pressed and dried, partially or totally lose morphological traits (e.g., shape or colour of the flower) that are essential for their identification (see example in Fig. 2): orchids, for instance, are usually underrepresented in herbaria (Nualart \& al., 2017a) and adding photographs with the lost characters may increase the number of specimens.
6 Special cases that might include: (i) the specimen to be vouchered is the only individual in a given locality even when the species is neither protected nor endangered, a criterion already mentioned in Mytnik-Ejsmont \& al. (2015); and (ii) holy species or species located in holy sites for the local communities. In these two cases, collecting small parts instead of whole individuals should be the norm in order to (i) avoid the local extinction of the species and (ii) as a sign of respect for the local people, respectively.

\section{FUSION VOUCHERS AND PHOTO VOUCHERS}

We give the name "fusion voucher" to specimens accompanied by illustrating photographs to distinguish them from specimens that do not include this graphic complement, but also from photographs of a plant with no physical specimen. The term "photo voucher"-already used by Funk \& al. (2017) - refers to this last case, where no specimen has been collected and only photographs are available to document the presence of a plant in a given locality. Photo vouchers, therefore, are neither a specimen nor an alternative to a herbarium voucher: according to Art. 8 of the $I C N$, "a specimen is a gathering, or part of a gathering, of a single species or infraspecific taxon $[\ldots]$ A specimen is usually mounted on a single 

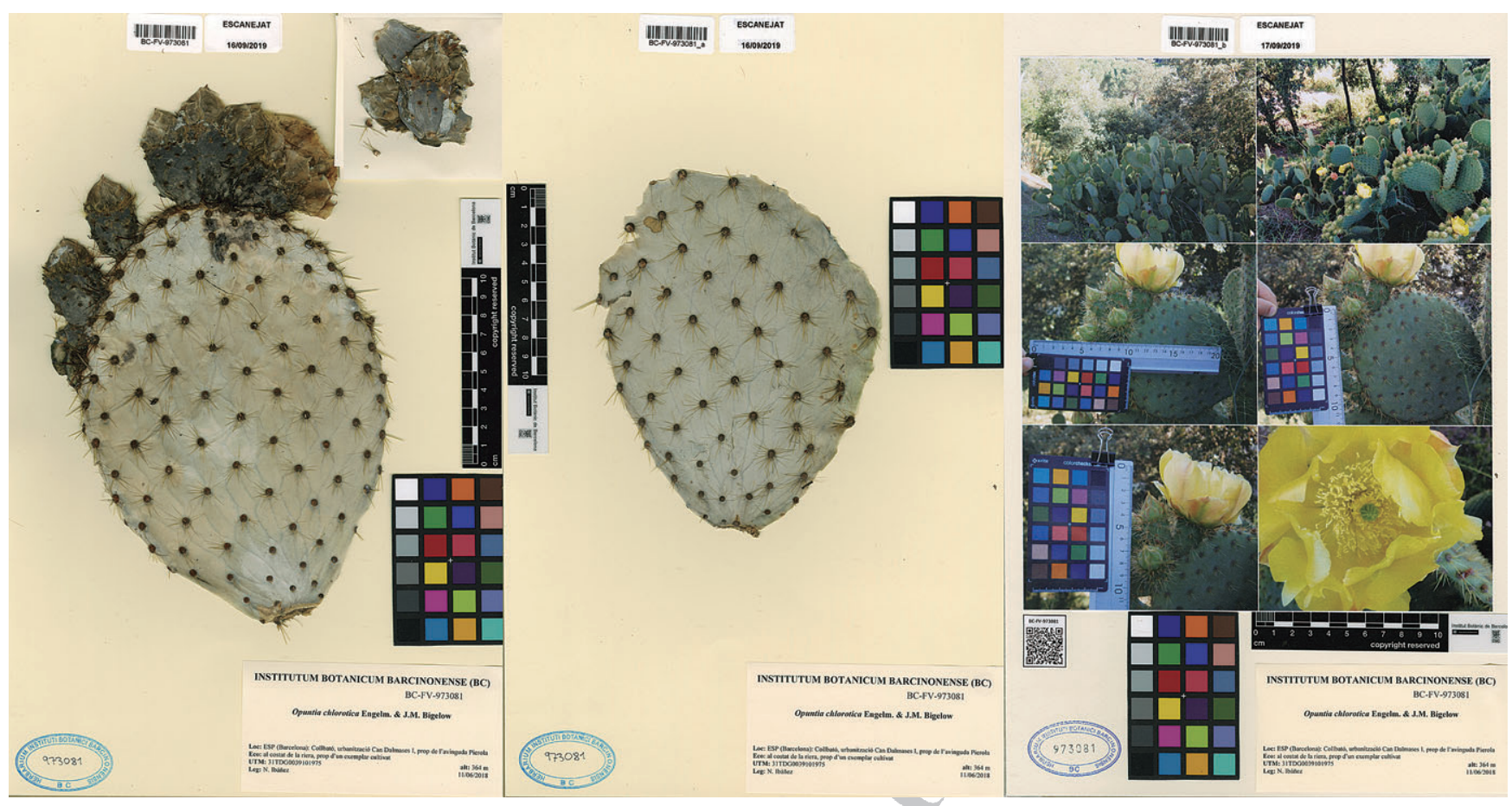

Fig. 2. Fusion voucher of Opuntia chlorotica Engelm. \& J.M.Bigelow (BC-FV-973081) in Collbató (Catalonia, Spain). This species is identified by the colour of the style and stigma, a character that is lost when the flower is dried. Moreover, Opuntia samples are difficult to dry because of the presence of spines.

herbarium sheet or in an equivalent preparation, such as a box, packet, jar, or microscope slide." However, difficulties in getting herbarium specimens under certain circumstances is a problem that botanists face more and more frequently, and the possibility of making a photo voucher in these cases should be taken into account.

It is clear that a photo voucher is a poor solution compared to a herbarium specimen. Funk \& al. (2017), who worked the most to rationalize the issue of vouchers, do not recommend it as a first option and suggest that whenever possible new visits to the locality should be carried out until a herbarium specimen is obtained. A herbarium specimen will always be more useful, because (1) it provides a good source for research, both basic and applied - even a small piece of the plant provides sufficient raw material for DNA studies (Nualart \& al., 2017b), and (2) some morphological characters could be hidden, or be too small or even invisible in two-dimensional images (Culley, 2013). However, we can enlist a number of situations where it is impossible to collect material, and a quality photographic document may be the only option. Even in the case that a photo voucher is used, Funk \& al. (2017) recommend "photographs should clearly indicate reproductive structures as well as habit and any characters that are useful for unambiguous species identification".

Photo vouchers may be the only form of documenting the presence of a plant in a given locality in at least two cases:

1 Protected plants, either because the species itself is protected by law (see example in Fig. 3), or because the population is included within a protected area. While this is the most frequent case (Minteer \& al., 2014; Funk $\&$ al., 2018), it is also important to consider that the increasing international regulations for the collection of protected species, such as CITES trade-regulations of 1975 (https:// www.cites.org/eng/disc/what.php) and the Nagoya protocol of 2014 (https://www.cbd.int/abs/about/), make their sampling even more restricted. For species that are on the verge of extinction and listed as CR or EN following the IUCN (2001) categories and criteria, it is not advisable to sacrifice a single individual from a population to obtain a specimen, even if it is not protected by law (quite a common situation in low-income countries).

2 Plants in inaccessible places, such as cliffs, caves or chasms, or roofs (see example in Fig. 4; plants can appear spontaneously on roofs, usually escaping from nearby green balconies and terraces).

\section{- A PROPOSAL OF STANDARDIZATION OF PHOTOGRAPHS}

Either accompanying a specimen or not, it is necessary to develop a protocol with standards that photographs must meet as a reference material for a given locality of a given plant taxon; standards must fulfil criteria of maximum efficiency, ease and usefulness. First, photographs must comply with a series of technical requirements: (i) photographs should allow 


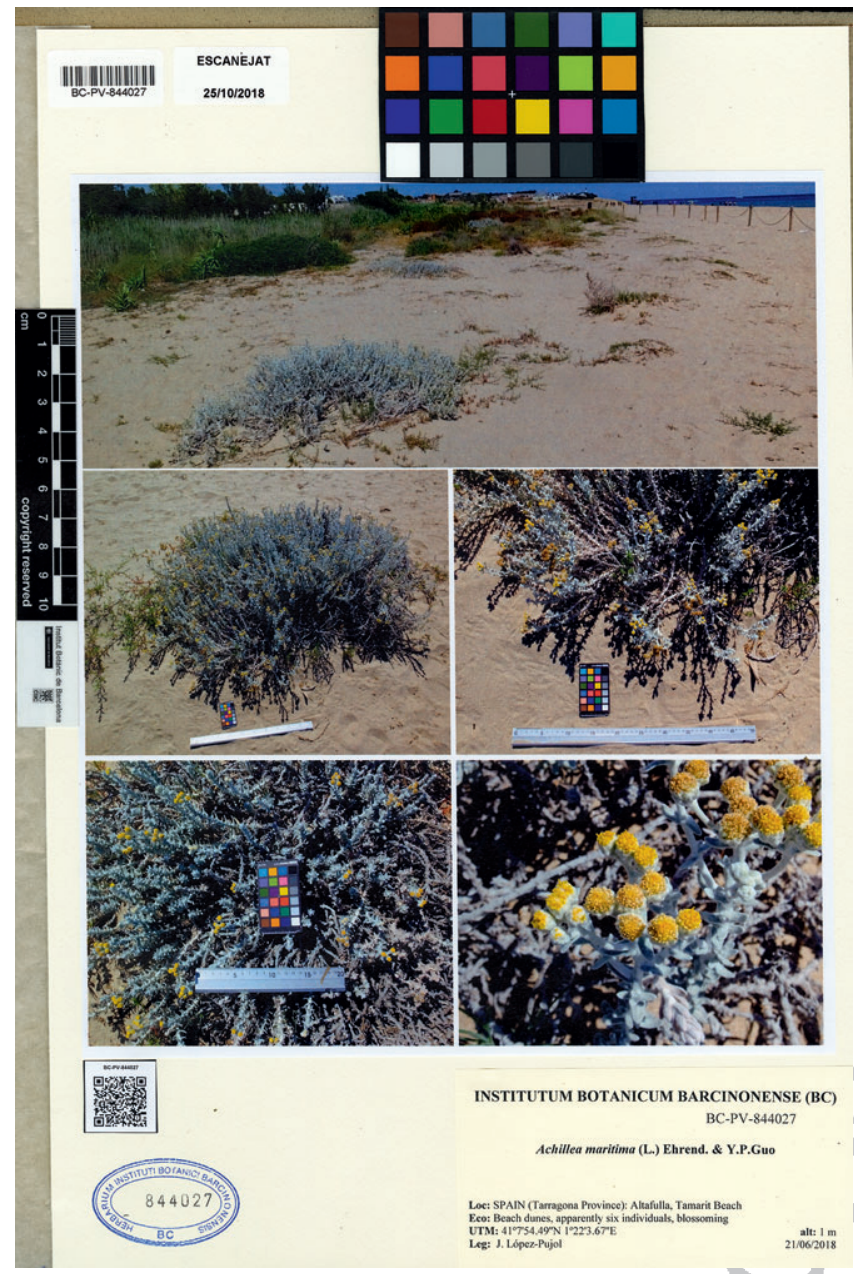

Fig. 3. Photo voucher of Achillea maritima (L.) Ehrend. \& Y.P.Guo (BC-PV-844027) in a small, recently discovered population with only six individuals in Tarragona (Catalonia, Spain). This species is strictly protected by law at regional level (DARPAMN, 2015).

the accurate identification of the plant, and (ii) photographs must reflect the entire size of the plant as well as the habitat where it occurs (Figs. 1-4). When there is more than one individual of the focus species, or when there are different species in the photograph, a red arrow should be included to identify the individual on which the voucher is based (Figs. 1B, 4). As a general rule, detailed photographs should be taken of the main organs (leaves, flowers, inflorescences, and fruits) and also of any character (spines, indument, etc.) that could help in the correct determination of the taxon. A particular case will be species that are monocarpic (e.g., some species of Agave L.), where it is not possible to photograph the same specimen with flowers and green leaves at the same time (Fig. 1). For these cases, we recommend taking photographs of different individuals within the same population - a vegetative individual and a flowering one. As an additional suggestion, we strongly recommend (indeed, it is a standard in BC) the use of a ruler and, if possible, a standard colour chart like

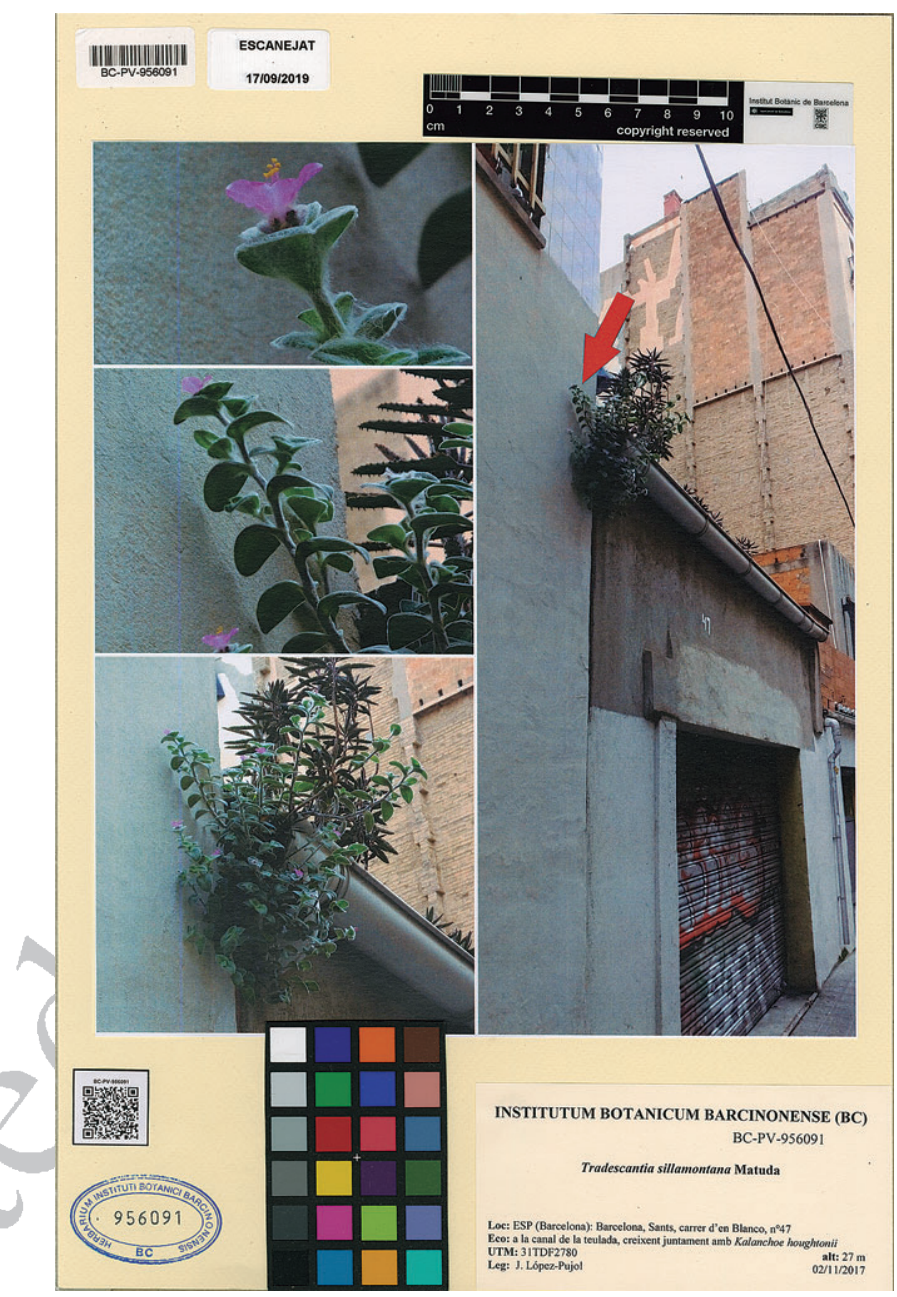

Fig. 4. Photo voucher of Tradescantia sillamontana Matuda (BC-PV956091) from a population in Barcelona city centre (Catalonia, Spain). Please note that the use of ruler and colour chart was not possible here. The red arrow in the photograph of the habitat helps the researchers to identify the species on which the voucher is based.

Pantone (Figs. 1-3). As far as possible, these tools should be placed on the same plane as the sample, and in such a way that excessive illumination and backlighting be avoided.

Thus, a fusion or a photo voucher should consist of a variable number of photos of a given plant with sufficient resolution (300 ppi) and taken at a known date and location. Photographs must be accompanied by the essential data of any herbarium specimen such as scientific name, collector, date and place of collection, ecology and other data considered of interest. Ideally, all these data should be incorporated in a collections management program such as Brahms (https://herbaria.plants.ox.ac.uk/bol/), Specify (http:// specifyx.specifysoftware.org/) or Elysa (https://www.gbif.es/ software/elysia/), or any other program used in the herbarium that include the kind of preparation (sheet, fruit, seed, photo, tissue ...) as one of the fields. Precise geolocation of the collected specimen is also necessary; a minimum resolution of 1 arc-min is recommended. Exceptions may apply for
57

58

59

60

61

62

63

64

65

66

67

68

69

70

71

72

73

74

75

76

77

78

79 
critically endangered species, for which a too detailed georeferencing may add additional risk.

Fusion vouchers should be deposited in herbarium collections because they are specimens (i.e., they include a physical sample). In the case of photo vouchers, there is no common pattern of how to deposit them in the (few) herbaria that are already hosting them; for example, AAU (Herbarium of Aarhus University) is not giving them a number or other registration code (e.g., Calathea varians (K.Koch \& L.Mathieu) Körn.; http://www.aubot.dk/show_entry.php?CatalogNumber= K.Shigematsus.n.\&\&sp_set $=$ all\&identification $=$ calathea $\%$ 20varians). In contrast, two herbaria specialized in succulent plants, the Desert Botanical Garden Herbarium (DES; e.g., Dudleya saxosa subsp. collomiae (Rose) Moran, http:// swbiodiversity.org/seinet/collections/individual/index.php? occid $=8553404)$ and the University of Arizona Herbarium (ARIZ; http://www.conabio.gob.mx/otros/herbario/arizona/ 265486.jpg), treat photo vouchers in a similar way to specimens (i.e., giving them a catalogue number and including a specimen label). Although photo vouchers do not include plant samples, we strongly recommend depositing them in a herbarium or public institution and making them available to be consulted by researchers. Once they are incorporated in a public herbarium, a unique registration number will be assigned like any specimen, using an acronym (in BC, we use the acronym "FV" or "PV") to indicate that it is a fusion voucher (e.g., BC-FV-registration number) or a photo voucher (e.g., BC-PV-registration number). For practical reasons we recommend incorporating both fusion vouchers and photo vouchers physically in the herbarium, with the printed photographs mounted as a specimen. It is important, however, that the hosting herbarium provides a system to view the photographs in high resolution as a part of an accessible digital repository (offline or, whenever possible, online, like international portals such as GBIF [https://www.gbif.org/] or MorphBank [http://www.morphbank.net/]). Systems may include a QR code label accompanying each voucher (as we do in BC; Figs. 1-4), and a link, when applicable, to a germplasm, DNA, or tissue bank. Once the images are catalogued with a registration number, they become the property of the institution to which the herbarium belongs. It is important to obtain the copyright (Creative Commons) authorizing the use of the images at the time the donation is made to the herbarium.

The purpose of standardizing photographs is that they might be a complement or an alternative that could alleviate the consequences of the impossibility of obtaining a complete specimen (in the case of fusion vouchers) or a specimen at all (in the case of photo vouchers). High-quality photo vouchers may be useful as a working tool for taxonomic purposes, both for publication in articles and for floristic, chorological, or molecular works. Standardizing and incorporating these kinds of vouchers in herbaria and plant collections represents a significant improvement in order to solve the underrepresentation in herbaria of the species more difficult to collect, such as plants that would result in very large specimens (SchmidtLebuhn \& al., 2013; Daru \& al., 2018), spiny, thorny or prickly plants (Schmidt-Lebuhn \& al., 2013), or threatened species (Daru \& al., 2018).

\section{AUTHOR CONTRIBUTIONS}

JL-P conceived the manuscript; all authors drafted and read several versions of the manuscript. - CG-B, http://orcid.org/0000-0002-2468158X, cgomezbellver@gmail.com; NI, http://orcid.org/0000-00018228-4016, nibanez@ibb.csic.es; JL-P, http://orcid.org/0000-00022091-6222,jlopez@ibb.csic.es; NN, http://orcid.org/0000-0001-5804387X, nnualart@ibb.csic.es; AS, https://orcid.org/0000-00034717-9063

\section{ACKNOWLEDGEMENTS}

When this paper was in press, we received the sad news of the passing of Vicki Ann Funk (1947-2019), who stressed upon the importance of vouchers and discussed the issues addressed by us in Taxon (Funk $\&$ al., 2018). Vicki, sit tibi terra laevis.

We thank the staff of our herbarium for their assistance in preparing the photo vouchers and fusion vouchers depicted in the figures: Eduard Farràs and Diana Muñiz. We also thank Alexey Seregin (MW) for his helpful suggestions.

\section{- LITERATURE CITED}

Brickell, C.D., Alexander, C., Cubey, J.J., David, J.C., Hoffman, M. H.A., Leslie, A.C., Malécot, V. \& Jin, X.B. 2016. International Code of Nomenclature for Cultivated Plants, 9th ed. Scripta Horticulurae 18. Leuven: International Society for Horticultural Science (ISHS).

Culley, T.M. 2013. Why vouchers matter in botanical research. Applic. Pl. Sci. 1: 1300076. https://doi.org/10.3732/apps. 1300076

DARPAMN (Departament d'Agricultura, Ramaderia, Pesca, Alimentació i Medi Natural, Generalitat de Catalunya) 2015. Resolució AAM/732/2015, de 9 d'abril, per la qual s'aprova la catalogació, descatalogació i canvi de categoria d'espècies i subespècies del Catàleg de flora amenaçada de Catalunya. Diari Oficial de la Generalitat de Catalunya 6854: CVE-DOGC-A15106031-2015.

Daru, B.H., Park, D.S., Primack, R.B., Willis, C.G., Barrington, D. S., Whitfeld, T.J.S., Seidler, T.G., Sweeney, P.W., Foster, D.R., Ellison, A.M. \& Davis, C.C. 2018. Widespread sampling biases in herbaria revealed from large-scale digitization. New Phytol. 217: 939-955. https://doi.org/10.1111/nph.14855

Funk, V.A., Gostel, M., Devine, A. Kelloff, C.L., Wurdack, K., Tuccinardi, C., Radosavljevic, A., Peters, M. \& Coddington, J. 2017. Guidelines for collecting vouchers and tissues intended for genomic work (Smithsonian Institution): Botany best practices. Biodivers. Data J. 5: e11625. https://doi.org/ 10.3897/BDJ.5.e11625

Funk, V.A., Edwards, R. \& Keeley, S. 2018. The problem with(out) vouchers. Taxon 67: 3-5. https://doi.org/10.12705/671.1

IUCN (International Union for Conservation of Nature) 2001. IUCN Red List Categories and Criteria: Version 3.1. Gland and Cambridge: IUCN Species Survival Commission.

Miller, D.M. 1995. Standard specimens for cultivated plants. Acta Hort. 413: 35-40. http://www.actahort.org/books/413/413_6.htm

Minteer, B.A., Collins, J.P., Love, K.E. \& Puschendorf, R. 2014. Avoiding (re) extinction. Science 344: 260-261. https://doi.org/ $10.1126 /$ science. 1250953 
Mytnik-Ejsmont, J., Szlachetko, D.L., Baranow, P., Jolliffe, K. \& Górniak, M. 2015. Phylogenetic placement and taxonomy of the genus Hederorkis (Orchidaceae). PLoS ONE 10: e0122306. https://doi.org/10.1371/journal.pone.0122306

Nualart, N., Ibáñez, N., Luque, P., Pedrol, J., Vilar, L. \& Guàrdia, R. 2017a. Dataset of herbarium specimens of threatened vascular plants in Catalonia. PhytoKeys 77: 41-62. https:// doi.org/10.3897/phytokeys.77.11542

Nualart, N., Ibáñez, N., Soriano, I. \& López-Pujol, J. 2017b. Assessing the relevance of herbarium collections as tools for conservation biology. Bot. Rev. (Lancaster) 83: 303-325. https://doi.org/ 10.1007/s12229-017-9188-z
Schmidt-Lebuhn, A.N., Knerr, N.J. \& Kessler, M. 2013. Nongeographic collecting biases in herbarium specimens of Australian daisies (Asteraceae). Biodivers. \& Conservation 22: 905-919. https://doi.org/10.1007/s10531-013-0457-9

Turland, N.J., Wiersema, J.H., Barrie, F.R., Greuter, W., Hawksworth, D.L., Herendeen, P.S., Knapp, S., Kusber, W.-H., Li, D.-Z., Marhold, K., May, T.W., McNeill, J., Monro, A.M., Prado, J., Price, M.J. \& Smith, G.F. (eds.) 2018. International Code of Nomenclature for algae, fungi, and plants (Shenzhen Code) adopted by the Nineteenth International Botanical Congress Shenzhen, China, July 2017. Regnum Vegetabile 159. Glashütten: Koeltz Botanical Books. https://doi.org/10.12705/Code.2018 